\title{
Analyzing the Establishment of Community Forestry (CF) and Its Processes Examples from the South West Region of Cameroon
}

\author{
Mbolo C. Yufanyi Movuh ${ }^{1}$ \\ ${ }^{1}$ Institute for Forest Policy and Nature Conservation, Faculty of Forest Sciences and Ecology, Georg-August \\ University Goettingen, Büsgenweg, Germany \\ Correspondence: Mbolo C. Yufanyi Movuh, Institute for Forest Policy and Nature Conservation, Faculty of \\ Forest Sciences and Ecology, Georg-August University Goettingen, Büsgenweg 3, 37077 Göttingen, Germany. \\ Tel: 49-170-8788124. E-mail: cyufani@gwdg.de
}

\author{
Received: November 14, 2012 Accepted: December 20, 2012 Online Published: December 26, 2012 \\ doi:10.5539/jsd.v6n1p76 \\ URL: http://dx.doi.org/10.5539/jsd.v6n1p76
}

\begin{abstract}
This paper reconstructs and analyzes the establishment of the Community Forestry (CF) processes in Cameroon, questioning the extent to which the CF models can act as a decentralization and devolution tool. It includes community based natural resource management through programs/projects emphasizing biodiversity conservation and sustainable forest management directly involving the local communities. Thirteen communities were explored in the South West Region (SWR) of Cameroon. Samples selection was based on information about recent activities of the communities in the CF process. From this population, a simple random selection and later quantitative and qualitative interviews were carried out with more than 70 different stakeholders through their networking and interest representation in CF. Analysis show that the CF process is centralized, slow, long, complex and expensive, making it difficult for local communities to be an active part in policy implementation. Results also confirm that decentralization and devolution for sustainable local forest governance could offer the communities an opportunity to derive livelihoods from their forests, but the models and processes have also inhibited them through centralized control of the state and its development partners. Furthermore, it shows that $\mathrm{CF}$ as a decentralization tool has not really functioned.
\end{abstract}

Keywords: community forest, council forest, decentralization, devolution, Cameroon

\section{Introduction}

Forests are natural resources as well as public goods that need to be managed in the interests of local, regional and global posterity. Effective governance of forest resources involves difficult choices and reforms. Decentralization aproaches in forest governance seem to be the right answer to tackle forest protection issues involving local people (Glück et al., 2005; Devkota, 2010). Oyono (2004b) defines decentralization as, "a process through which powers, responsibilities and resources are devolved by the central state to lower territorial entities and regionally/locally elected bodies, increasing efficiency, participation, equity, and environmental sustainability". Likewise, Ribot (2004) sees decentralization and devolution as, "any act by which central government formally cedes powers to actors and institutions at lower levels in a political-administrative and territorial hierarchy". Nevertheless, a number of researchers (Ribot, 2004; Ribot, 2009; Larson, 2005; Blaikie, 2006; Dahal \& Capistrano, 2006) have analyzed the common practice and have shown that the decentralization policy in forest resources is seldom followed by genuine power devolution to the local users.

Following the above mentioned definitions of Oyono and Ribot, importance is placed on the role of the central government in achieving increased efficiency, participation, equity, and environmental sustainability. To contribute to the discourse, this article will analyze the establishment of CF in Cameroon to investigate if it has functioned as a tool for decentralization. It uses the CF models in Cameroon through its establishment and processes to analytically test the decentralization paradigm with empirical data. It does not want to explain CF using theory but test if the theoretical framework has been or is being successful implemented in CF. The main question is, "if CF has been successful as a tool for forest management decentralization?", a paradigm which has found place on paper and the rhetoric of the Cameroonian government and bi/multilateral organizations. It is not in the scope of this paper to address "common pool resources" or "communal land management", which is a broad field with many alternative institutional features in "governing the commons" (Ostrom, 1990). The scope 
of this paper is limited to reconstruction of $\mathrm{CF}$ establishments and processes as perceived by the main stakeholders in CF.

\subsection{Community Forestry and Its Establishment in Cameroon}

Community forestry (CF) came into prominence in the 1970s, when the UN Food and Agriculture Organisation (FAO) in 1978 initiated activities and programs related to rural communities and their forest-related activities. Here, CF was defined as "any situation which intimately involves local people in a forestry activity" (FAO, 1992). McDermott \& Schreckenberg (2009:158) go further to specify that, "community forestry refers to the exercise by local people of power or influence over decisions regarding management of forests, including the rules of access and the disposition of products". The 1994 Cameroon Forestry law defines it as "a forest forming part of the non-permanent forest estate, which is covered by a management agreement between a village community and the Forestry Administration" (RoC, 1994, Note 1). For this paper, CF is seen as "forestry or forest practices which directly involve(s) local forest users in the common decision making processes and implementation of forestry activities". The present models of Community and Council Forestry in Cameroon fall within the scope of the FAO definition and also that of the study. Furthermore, the Forest Policy of Cameroon through the forestry law as well as the Forest Environment Sector Program (FESP/PSFE), seeks to empower the local institutions in the sustainable management of their forest resources for their benefits through the creation and the management of Council and Community forests. Community forest management has been and is still being experienced in the South West Region (SWR) for years but the concept of Council forest management is said to be new. This paper uses CF to refer to both community and council forests and where appropriate each model will be specified. This is possible since CF is a general term used to refer to a variety of models of community management of forest resources, while the paper focuses more on the local forest users.

According to the 1992 statistics of the International Union for Conservation of Nature (IUCN), Cameroon has a national forest cover of $41.2 \%$ of the land area $\left(155,330 \mathrm{~km}^{2}\right)$ (IUCN, 1992), constituting one of its major economic resource (Yufanyi Movuh, 2008). The strife for decentralization and devolution of forest management led to changes in state policy towards natural resources particularly forest resources. In 1993, a national land use plan or zoning plan (plan de zonage) was conducted in Cameroon, dividing forest areas into a permanent and non-permanent forest zones. Community forests are part of the non-permanent forest zone but as Etoungou (2003) pointed out, Cameroon's Forest Zoning Plan allocates only 2\% of the national estate to Community forests. Likewise, part of the permanent forest estate falls under state forests, which are directly under state control or under the control of Councils as council forests, in their status as local government units, subject to a simple management plan (Mandondo, 2003). State forests are permanently classified as national parks, reserves, sanctuaries, botanical parks and gardens as well as game ranches, used for different purposes like for production, reforestation, recreation, protection, research and education. Just like the Community forest model, there are legal options to create and manage Council forests in Cameroon (1994 Forestry law, Article 21). The Legal procedures to be undertaken to create and manage council forests are clearly outlined in the corresponding texts of application (Mambo, 2006). These procedures are explained as perceived by stakeholders concerned, also with the use of practical examples, in the later section.

With the 1994 established forestry law aiming at overhauling the national forest policy, one of its main objectives was the improvement of the participation of the population in the conservation and the management of forest resources, in order to contribute to the elevation of livelihood (RoC, 1994). The law and its decrees of application were enacted in 1995. It created a model Community forestry as part of a non-permanent forest estate whose process of gazettement would be accompanied with technical assistance by the Ministry of Forestry and Wildlife (MINFOF), free of charge so as to promote the model. Quoting Oyono (2005a:322), Community forests were meant to be a new and potentially very innovative class of forest exploitation unit, by which it was intended that, for the first time in Cameroon's history, rural populations can gain direct, legal access to forest products, including timber, with some limitations. Management of such forest is the responsibility of the village community concerned, with the technical assistance of the administration in charge of forests (Sobze, 2003). This implies that through contracts from the administration in charge of forests, part of the national forest is entrusted to a village community for its management, conservation and use for the interest of the community. For a council forest, although there are no limitations in surface area, the process is more or less similar, still with a handful of other constraints. Also like Community forests, stakeholders for Council forests could be assisted by the forestry administration, NGOs or the private sector including timber companies (RoC, 1994; Yufanyi Movuh, 2012). 
This paper is in sequence with our comparative study analysis of the interests and power of the stakeholders involved in Community Forestry (CF) in six countries, under the auspices of the Community Forestry Working Group (CFWG) in Goettingen (Note 2), Germany. The comparative study hypothesizes that, "governance processes and outcomes in CF depend mostly on interests of the powerful external stakeholders". Being the main research person for Cameroon in the group and for this paper, I will pay particular attention just on the processes leading to the acquisition of $\mathrm{CF}$ since much has already been published for Cameroon, on the above hypothesis (see Yufanyi Movuh, 2012; Yufanyi Movuh \& Schusser, 2012). This is to enable a broader understanding of the constraints faced by communities in the acquisition of CF in Cameroon. Many studies have been conducted in the field of CF in Cameroon (Etoungou, 2003; Mandodo, 2003; Sobze, 2003; Mambo, 2004; 2006; Ribot, 2004; Oyono, 2004a,b; Oyono 2005a,b; Oyono, 2009; Yufanyi Movuh, 2012; Yufanyi Movuh \& Schusser, 2012), but there has not been a straight and simple analysis of the establishment of the CF processes, directly involving the local forest users, making it possible to understand the present impediments entangled to these processes. This paper is important in linking these processes and their constraints pertaining to the present situation and it questions the extent to which CF can act as a decentralization and devolution tool for local forest resource management. It falls in line with the above mentioned works but it also gives a detailed analysis with some practical examples.

\section{Method}

This research study's definition of CF also includes community based natural resource management through programs/projects emphasizing biodiversity conservation and sustainable forest management involving the local communities (Yufanyi Movuh \& Schusser, 2012). As mentioned above, the practice of council forestry in Cameroon is included as part of the CF. Thirteen communities (see Figure 1 and Table 1) were explored in the SWR of Cameroon between 2009 to 2011. It is an area where the researcher has a good existing knowledge. The selections of the community and council forestry samples were done with the map of the PSMNR-SWR (see Figure 1, showing the different forest zones) and based on information on recent activities of the communities in the CF process (Note 3). A total of 18 community forest and 2 council forests were identified using the map (Note 4). From this population, a simple random selection was implemented. Interviews conducted with more than 70 different stakeholders in the selected samples were in relation to the information given by other stakeholders in their networking (Schnell et al., 2005) and interest representation in CF (Note 5). Quantitative and qualitative interviews were carried out with CF Managers and Forestry officers and at times with members of the Common Initiative Groups (CIG) and Village Forest Management Committees (VFMC), responsible for the management of these forests, with representatives of MINFOF- SWR and KfW/GFA (German development bank/German consulting firm) representing the main Program (PSMNR-SWR) for the facilitation of the implementation of the forestry law, hence CF. Documents like Logframe of the PSMNR-SWR, Management Plans (MP) and Technical Notes (NT) of the CFs were also part of the materials collected and analyzed. The sequence design (Schusser et al., 2012) for network analysis uses, "(1) a quantitative preliminary survey - (2) a qualitative survey and (3) a quantitative follow-up study, which focuses the observations on preselected subjects in order to save resources during the field work" (Schusser et al., 2012: 75). The preliminary quantitative survey identifies the powerful actors of the network while the qualitative analysis goes deeper to describe and evaluate the powerful stakeholders, identified through the quantitative network analysis (ibid: 6). 


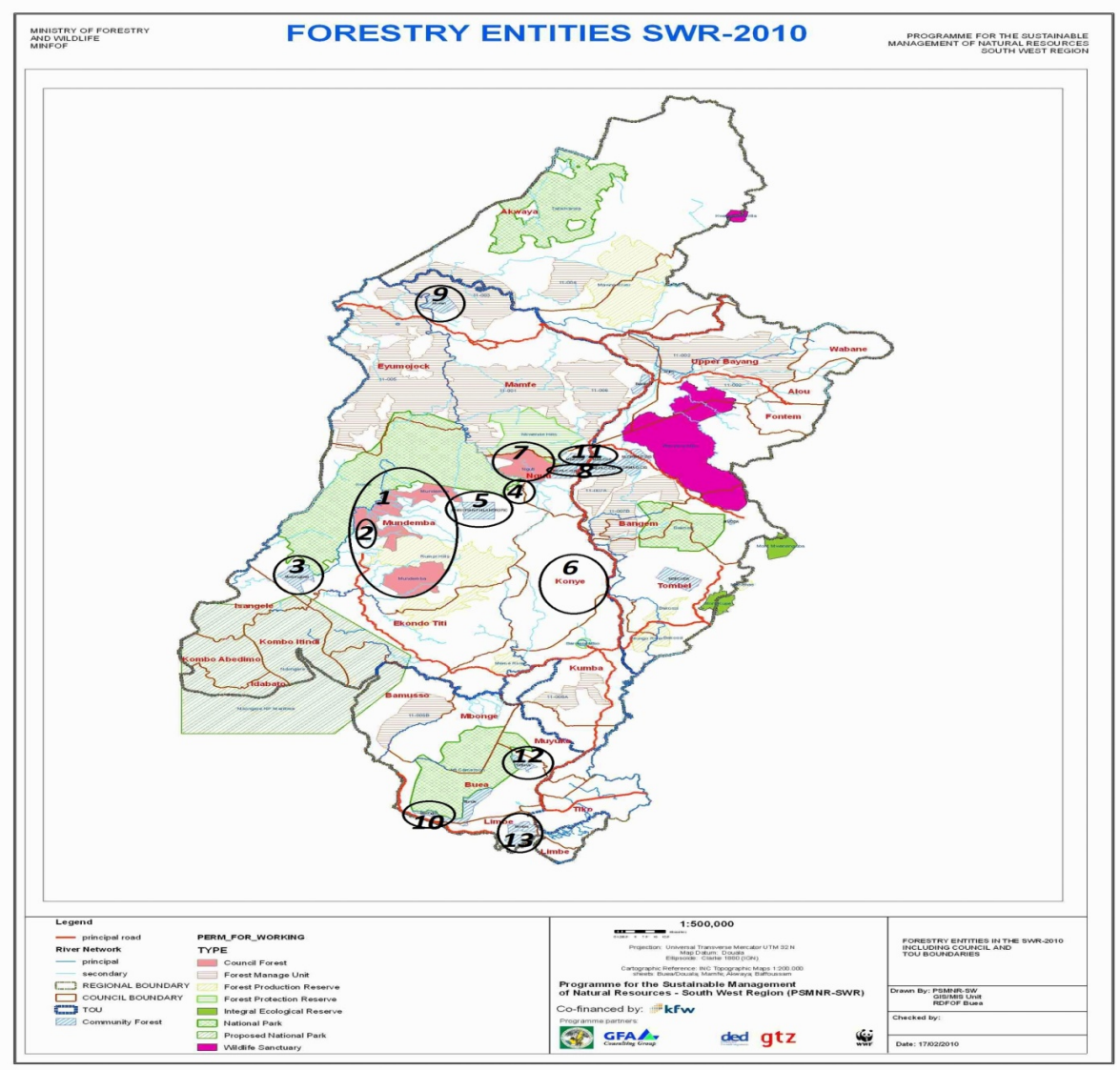

Figure 1. Community and Council Forestry regions in the PSMNR-SWR: Areas visited are encircled Source: PSMNR 2010, published in Yufanyi Movuh \& Schusser, 2012.

First, a quantitative network analysis was conducted, exploiting the knowledge of the stakeholders to identify the partners of the network and later, a qualitative analysis went deeper to describe and evaluate the powerful stakeholders, identified through the quantitative network analysis. All the interviews were recorded for transcription and further analysis. Although the main purpose of the comparative research was to identify and analyze the interests, influence of powerful stakeholders within the CF network and the outcomes of CF, the objective of this paper is limited to reconstructing and analyzing the establishment of the CF processes in Cameroon. Details of the methodology are analyzed in Schusser et al. (2012), Yufanyi Movuh (2012), Yufanyi Movuh and Schusser (2012).

\section{Results}

The results of this paper are based on empirically collected quantitative and qualitative data during the research period. It gives a step to step analysis (as perceived by most stakeholders interviewed) of how CFs are established and the different processes involved, using some practical examples. The results also entail a recollection, analysis and qualitative interpretations of the different stakeholders interviewed. From the thirteen CFs visited between 2009 and 2011, ten CFs carried out activities perceived to conform with the CF definition for the study and also MINFOF classification as a CF. Table 1, shows the different cases of CF analyzed, indicating the presence or not, of donor involvement in the form of development assistance to the government of Cameroon through MINFOF and the PSMNR-SWR to the CF. The results analysis in relation to decentralization and devolution are based on the CF procedures, follow-up steps, participation, time taken for gazettment, complexity and expenses. 
Table 1.General information of the selected community and council forests (CFs) in the SWR of Cameroon

\begin{tabular}{|c|c|c|c|c|c|}
\hline Communit(y)ies & Forest status & $\begin{array}{l}\text { Name of Management } \\
\text { Institution }\end{array}$ & $\begin{array}{l}\text { Resource } \\
\text { status }\end{array}$ & $\begin{array}{l}\text { Donor } \\
\text { involvement }\end{array}$ & Visited \\
\hline Mundemba & $\begin{array}{l}\text { Council } \\
\text { Forest, } \\
\text { Reserved }\end{array}$ & $\begin{array}{l}\text { Mundemba rural council } \\
\text { (Ndian) }\end{array}$ & Rich & $\begin{array}{l}\text { Yes, GIZ } \\
\text { (GTZ) }\end{array}$ & $2009 / 2011$ \\
\hline Ikondo Kondo & $\begin{array}{l}\text { Community } \\
\text { Forest (not } \\
\text { exsting } \\
\text { anymore) }\end{array}$ & $\begin{array}{l}\text { Mundemba rural council } \\
\text { (Ndian) }\end{array}$ & Rich & $\begin{array}{l}\text { Not anymore } \\
\text { but } \\
\text { previously } \\
\text { GTZ }\end{array}$ & $2009 / 2011$ \\
\hline Mosongiseli & $\begin{array}{l}\text { Community } \\
\text { Forest, } \\
\text { Reserved }\end{array}$ & $\begin{array}{l}\text { Mosongiseli Balondo } \\
\text { Badiko CIG } \\
\text { (MBABCIG) (Ndian) }\end{array}$ & Rich & $\begin{array}{l}\text { Yes, GIZ } \\
\text { (DED) }\end{array}$ & $2009 / 2011$ \\
\hline Toko & $\begin{array}{l}\text { Council } \\
\text { Forest, (not } \\
\text { exsting } \\
\text { anymore) }\end{array}$ & $\begin{array}{l}\text { Toko rural council } \\
\text { (Ndian) }\end{array}$ & Poor & $\begin{array}{l}\text { Not anymore } \\
\text { but } \\
\text { previously } \\
\text { GTZ }\end{array}$ & $2009 / 2011$ \\
\hline Itali & $\begin{array}{l}\text { Community } \\
\text { Forest, } \\
\text { Operational }\end{array}$ & $\begin{array}{l}\text { Christian Philanthropic } \\
\text { Farms and Missions } \\
\text { (CPFAM) CIG } \\
\text { (Ndian) }\end{array}$ & $\begin{array}{l}\text { Rich but } \\
\text { no access }\end{array}$ & No & $2009 / 2011$ \\
\hline Konye & $\begin{array}{l}\text { Council } \\
\text { Forest, (not } \\
\text { exsting } \\
\text { anymore) }\end{array}$ & $\begin{array}{l}\text { Konye Rural Council } \\
\text { (Meme) }\end{array}$ & Poor & $\begin{array}{l}\text { Not anymore } \\
\text { but } \\
\text { previously } \\
\text { GTZ }\end{array}$ & $2009 / 2011$ \\
\hline Nguti & $\begin{array}{l}\text { Council } \\
\text { Forest, } \\
\text { Reserved }\end{array}$ & $\begin{array}{l}\text { Nguti Rural Council } \\
\text { (Kupe-Muanengouba) }\end{array}$ & Rich & $\begin{array}{l}\text { Yes, GIZ } \\
\text { (DED) }\end{array}$ & $2009 / 2011$ \\
\hline Manyemen & $\begin{array}{l}\text { Community } \\
\text { Forest, } \\
\text { Operational }\end{array}$ & $\begin{array}{l}\text { REPA-CIG } \\
\text { (Kupe-Muanengouba) }\end{array}$ & Rich & $\begin{array}{l}\text { Not anymore, } \\
\text { but } \\
\text { previously } \\
\text { CAFECO }\end{array}$ & $2009 / 2011$ \\
\hline Akwen & $\begin{array}{l}\text { Community } \\
\text { Forest, } \\
\text { Reserved }\end{array}$ & Akwen CF(Manyu) & Rich & $\begin{array}{l}\text { Yes, GIZ } \\
\text { (DED) }\end{array}$ & $2009 / 2011$ \\
\hline Bakingili & $\begin{array}{l}\text { Community } \\
\text { Forest, } \\
\text { Reserved }\end{array}$ & $\begin{array}{l}\text { Bakingili CF } \\
\text { Management CIG } \\
\text { (Fako) }\end{array}$ & Poor & $\begin{array}{l}\text { Yes, GIZ } \\
\text { (DED) }\end{array}$ & $2009 / 2011$ \\
\hline MBACOF & $\begin{array}{l}\text { Community } \\
\text { Forest, } \\
\text { Reserved }\end{array}$ & $\begin{array}{l}\text { MBAAH Community } \\
\text { Forest CIG } \\
\text { (Kupe-Muanengouba) }\end{array}$ & nd & No & 2011 \\
\hline Woteva Village & $\begin{array}{l}\text { Community } \\
\text { Forest, } \\
\text { Reserved }\end{array}$ & $\begin{array}{l}\text { Woteva Village } \\
\text { Development CIG } \\
\text { (WODCIG) (Fako) }\end{array}$ & nd & $\begin{array}{l}\text { Yes, GIZ } \\
\text { (DED) }\end{array}$ & 2011 \\
\hline Bimbia-Bonadikombo & $\begin{array}{l}\text { Community } \\
\text { Forest, } \\
\text { Operational }\end{array}$ & $\begin{array}{l}\text { CF Management CIG } \\
\text { (Fako) }\end{array}$ & Poor & $\begin{array}{l}\text { Not anymore } \\
\text { but } \\
\text { previously } \\
\text { MCP }\end{array}$ & $2009 / 2011$ \\
\hline
\end{tabular}

Source: revised from Yufanyi Movuh \& Schusser, 2012 (nd = no data). 


\subsection{Community Forest: Acquisition Procedure}

For a Community or village interested in acquiring a community forest, a legal entity (Common Initiative Group - CIG or Association) is registered at the Ministry of Agriculture (Note 6). This entity then commences with the different steps of the acquisition process (Note 7). Generally, the most literate and respectful members of the community are elected into the Executive Committee of the legal entity (Mambo, 2004).

Step 1 is sensitisation: An elite of the area or the government (forestry administration) goes about where there is a non-permanent forest (fôrets du domaine nationale) to sensitise the villages in and around this type of forest about the possibilities to create a Community forest in that piece of land, not exceeding 5000 ha. There are Community forests with different surface areas and in the North West Region for example, there are community forests of about 72 ha (Babah II), which was a virgin forest. In this step, the interest of the population of the community involved is stimulated and this would subsequently lead to the decision to begin the process.

Step 2 is the demarcation: The community then carries out demarcation of the area where they intend to carry out their CF activities. This is a participatory field work with the village or villages, and the CF procedures insist that these boundaries should be natural boundaries (Note 8), where the villagers can easily identify. This is contrary to the Forest Management Units (FMUs) with technical capacities to demarcate boundaries, where concessionaire can use a GPS to locate a boundary in the field. The villages do not have these capacities.

Step 3 is the production of the map: This map is on the scale of 1:200.000 and has to be verified and approved by the National Institute of Cartography (NIC). The NIC checks and sees if this particular area does not fall under a particular land use (mining exploitation area or any other use) of the state. After checking, it rejects or approves it with their stamp, for the continuation of the process. The villagers pay for the checking mission of the NIC experts in the field for signing (approval) and producing the map.

Step 4 is the consultation meeting: The villagers now organise a consultation meeting with an overall objective of informing the surrounding villages, to seek their agreement and acceptance of the boundaries. During this meeting, the village(s) involved in the process present the map, announcing their intentions and the boundaries. If there are no objections from the neigbouring villages concerning the boundaries, the process conitnues. If a neighbouring village has a portion of land in the same area, they can jointly create the Community forest and then have a "collective convention" (Note 9) and the revenue can be shared according to the percentage surface area of the different villages. Another objective of the meeting is to set the management objectives in the creation of theCommunity forest, where the village(s) would decide for what purpose they would want to use the forest for; for example, timber exploitation or Non Timber Forest Products (NTFPs) exploitation, medicinal plants exploitation, protection of water catchment, protection of traditional shrine, etc, depending on their objectives. From this meeting, there is a key protocol documenting the minutes, (Procès- verbal de la Reunion de consultation) that results from it (Note 10). This document states the date and objectives of the meeting and all the representatives of the civil adminstration are invited and mentioned and their signatures included.

All these documents, the map produced, the minutes of the consultation meeting and the Article of Association (rules and regulation of the legal entity responsible for the community forest), etc, are compiled and an application letter is written to the Minister at MINFOF, to apply for a reservation letter for the demarcated area. This documents have to pass through the Chief of Post for MINFOF (Note 11), of the area, the divisional delegation of MINFOF and the regional delegation, which then sends them to MINFOF in Yaounde, the capital city of Cameroon. MINFOF Yaounde then checks the map and with its own GIS, sees if the demarcated boundary does not fall under a permannent forest and then approves or reject it. If it is well demarcated, the Minister then signs a reservation letter for that area to the Community.

With no reaction from MINFOF 60 days after the village(s) deposits their document at the regional delegation, the village is reserved the right to make an application directly to the minister at MINFOF Yaoundé. If there is still no reaction from Yaoundé 10 days after the direct deposition at the ministry in Yaoundé, the village(s) can consider their application as approved. Approval through such a channel makes it more difficult for the Communities to subsequently follow up, exploit and sell their products. When the reservation letter is signed, the next step would be for the Community to produce a Simple Management Plan (SMP) for the community forest. The SMP is elaborated by the Community through hired experts and sent back to MINFOF Yaounde for appoval. There is a new manual of procedures $(\mathrm{MoP})$ with rules and regulations guiding the creation of a community forest from MINFOF, but just like the old one, it does not assist the Communities much though a mandatory participatory inventory system for SMP was added. Since the SMP is a technical document that shows how the forest is going to be sustainably managed in a 5 years period, there is a commission that sits in Yaounde to evaluate the SMP. A skeleton of the SMP (or a guide), enumerating what steps are supposed to be followed in its 
elaboration. This can also be found with the Staff of the RIGC Project (Note 12). There is a guide to develop a SMP with titles and subtitles, with every step described inside. A Community has the right to choose if they want a sales of standing volume or if they want a community forest. This should be made clear to them before starting the public notice procedure.

This step was mandatory with the former requirements but at present, the new procedures (MoP) stipulates that a Community applying for a community forest can at the same time apply for a two years "Provisional Convention (PC)" (Note 13). This is because it was identified in the former procedures that communities were not financially viable to sponsor the elaboration of the SMP, which is costly (at least 5 million FCFA). The new manual came up with a new provision where Communities can exploit some timber for the elaboration of the SMP. Parallel to the signing of the letter of reservation, the $\mathrm{PC}$ is also signed, provided the forest is not in the zoning plan. During the two years of provisional convention (which includes already a map with the parcellaire stands as a reservation) money generated from the Community forest exploitation has to be used on multiple resource inventory, socio-economic study and a development plan. The village development plan activities have to be taken over in the SMP as they have been decided in a participative way and money from the Community forest should go towards those activities. Some timber can be exploited and sold as logs with special authorization.

When the SMP is approved, the village(s) will be called to sign the Management Convention (MC) at the local level between the village(s) and the senior divisional officer (SDO) who represents the Minister at MINFOF (Note 14). After the signing of the MC which is the final stage, implementation begins, and the village(s) are supposed to carry out an Annual Action (cutting) Plan (AAP) according to stipulations in the SMP (Note 15).

From the Communities listed in Table 1, only three have a MC at the moment (Manyemen, Itali and Bimbia-Bonadikombo), giving them the full authority to manage their resources. The Akwen CF also had a MC but due to outsatnding conflicts with other stakeholders, it was suspended. Furthermore, all the CFs started the process of acquisition not less than 5 years ago and the majority has still not arrived at the final status of signing the MC with MINFOF. Three CFs (Ikondo Kondo, Toko and Konye) became extinct due to long waiting periods.

\subsection{Council Forest: Acquisition Procedure}

Similar to Community forests with a CIG, for a council forest, the villages forming part of the Council forest should also form a legal body, the VFMC (Note 16). These two, are the main bodies within the village Community and villages within the municipal council respectively, responsible for the adjacent forests, follow up and running of the CFs (see Figure 1). They could be assisted by the forestry administration (MINFOF), NGOs or the private sector including timber companies. Here, some practical examples of Council forests will be used to describe the process of acquisition.

\subsubsection{Mundemba}

The initiation of the Mundemba council forest started in 2006 when experts of the German development bank (KfW) and the regional MINFOF (Buea) visited the Mundemba council to introduce the council forest idea (Mambo, 2006). A letter of intent (to MINFOF) to acquire a council forest was written and published at the concerned local council area and with no objections after a time, there was the sensitization phase, to inform the local communities about the intent. Because the intent was welcomed by the Communities, the technical note (TN) was written to include the maps which then went through the delegation of state property and land tenure (Ministry of State property and Land tenure). The TN is a document that highlights the various activities of the Council forest. After identification of the area, there were several sensitization meetings including a cross-section of other villages of the municipality, with the council forest acquisition as main goal.

Following these meetings, the council gave its approval to other partners to assist in the process. Formerly, the council had interest in Council forestry but did not know how to go ahead so it contacted MINFOF for technical support. Then the GTZ-ProPSFE elaborated the TN for the council, in consultation with the council. Subsequently, it was sent to Yaoundé for the Minister to sign together with the public notice. In the TN, the council identifies the area to be managed and elaborates the map of the area. Also within, the objectives of managing the Council forest and its different activities are listed. After the elaboration of the TN, the different communities have the duration of 3 months after the public notice publication, to oppose the plan. Although there was some opposition from the Ikondo Kondo village (Note 17), the council went forward with the acquisition according to the processes spelled out by the law. The council then carried out sensitization tours.

The maps and TN were then forwarded to MINFOF Yaoundé again, and later to the Prime Minister. During the consultation meetings for the Council forest, the chief of Post, the divisional delegate and regional chief for 
MINFOF (or representative), the civil administration (DO), local delegations (divisional delegates of the different ministries of the concerned area) were all involved and present, also with representatives of the Mundemba council. The file for acquisition is currently somewhere in Yaoundé between MINFOF and the Prime Ministry.

\subsubsection{Nguti}

The initiation of Nguti council forest started in 2006 when experts of KfW and MINFOF (Buea) visited the Nguti council to introduce the council forest idea (ibid). This was with the aim of preservation of the ecosystem (animal and plant species), and also for the council to derive benefits. For this, there was the demarcation of the council boundaries (with GPS). After the demarcation and other necessary procedures, likewise described above (Mundemba), the file was sent to the Prime Minister's office for the publishing of the public notice, later giving the council the power to continue with other activities including sensitization of administrative and local elites, the local population and the sitting of the classification commission (CC). The process or task of the CC entailed the identification of the council forest area in a map, the surface area measurement and the carrying out of the management inventory. Further steps were the authorization or approval of the application, followed by the carving out of the first annual cutting area. This is when the exploitation inventory is done (assessing the exploitable species).

There was also a meeting with the administrative elites and local authorities in the council chambers of Nguti. This was chaired by the regional delegate for MINFOF. Other delegates like those for Mines, tourism, agriculture, livestock; also the senior divisional officer (SDO) and a Member of Parliament and council personnel including the civil society were all present. After this, the council organized sensitization tours for the concerned communities or villages. These meetings were chaired by the sub -delegate for MINFOF. The Divisional Officer (DO-representing the SDO) was also present, with other representatives of the above mentioned ministries all present. The council together with MINFOF assembled all the required documents and sent to Yaoundé for gazettement. The elaboration of the management plan (MP) has to come after the gazettement. Although the elaboration of the MP was in progress, there was no gazettment yet.

The council forest classification and gazettment process can be summarized in 7 steps: Step (0) is the initiation of the process by the municipal council; (1) publishing of public notice of intention and subsequent preparation of technical note from preliminary information; (2) sensitisation of administrative authorities and local elites; (3) village to village sensitisation of the population; (4) formation of divisional classification commission headed by the SDO; (5) preparation of documents to be sent to Prime Ministry for signing; (6) documents transmitted to PM for signature; (7) decree signed and made available.

Presently, the Mundemba and Nguti councils are in step 6, where the documents are transmitted to the prime minister for signing. It is worth noting that these councils started the process since 2006 and are still awaiting positive results.

Figure 2 (Organogram) gives a brief overview of the different local institutions responsible for the acquisition and running of the CFs. It starts from bottom to top where an interested Community forms a CIG, or a VFMC. This CIG/VFMC (together with the council) subsequently follows-up the application and classification process of the CF (Yufanyi Movuh, 2012). 


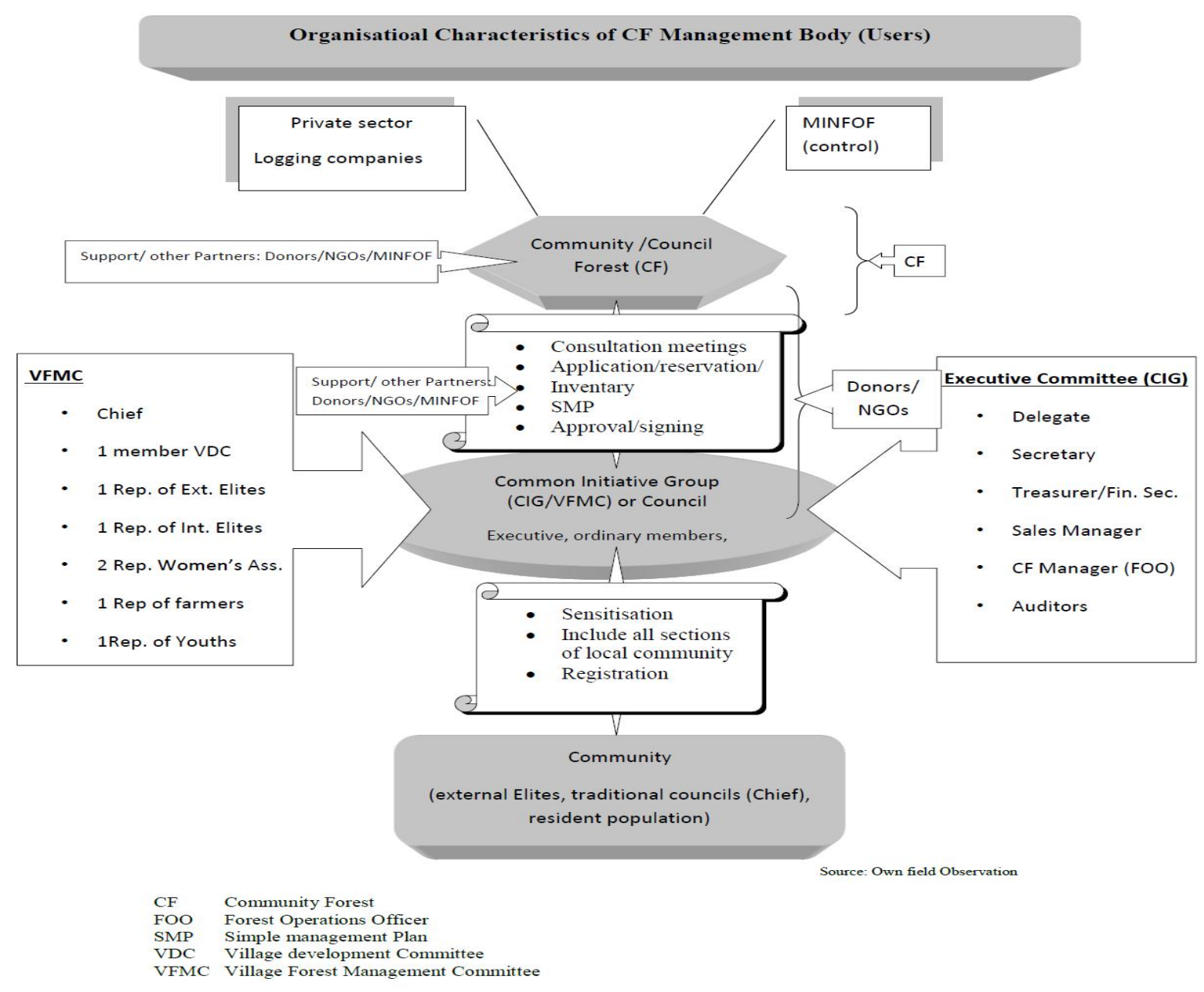

Source: Yufanyi Movuh (2012).

Figure 2. CF organogram

The forestry law (Note 18), introduced Annual Forest Royalties (AFR) payments to councils and local communities. For exploitation through a village(s) $\mathrm{CF}$, the total benefits are surrendered to the council and local communities, through negotiations with the stakeholders agreeing on a benefit sharing mechanism. For Community forests, the benefits are controlled by the CIG as stated in the SMP. For Council forests, $100 \%$ of the revenue goes into the council coffers supposedly to be strictly used for development. According to the joint ministerial Order MINTATD/MINFI/MINFOF no. 520 of $3^{\text {rd }}$ June 2010 explaining the sharing of forest revenue (Note 19$), 70 \%$ of the revenue is used for development of the entire municipality while $30 \%$ is paid directly to the concerned villages for development.

In the Nguti Council forest for example, there have been discussions with villages and there is a mechanism in the sharing of revenues. $30 \%$ of the revenues is for the villages surrounding the council forest area (originally their land which they have given up to the council), $20 \%$ is going to the management of this forest and $50 \%$ is going to the council. Nothing is going to the state anymore. The Council forest law states that these forests belong to the council. FMUs allocate tax benefits as follows: $50 \%$ to the State treasury, $40 \%$ to the concerned Council and $10 \%$ to the relevant villages. From the joint ministerial order No. 520, the royalty foreseen for the council (40\%) was split between the council (20\%) and FEICOM (Special Fond for inter-council equipment and interventions) (20\%). In the same mechanism, specialised software (GIS) can be used to calculate the areas of forest attributable to different villages as well as their timber potential, also for calculating benefits for each village.

In the last 15 years, following the limited success in implementation of the Community forest concept in the SWR in particular and Cameroon at large, donor organizations especially the German Cooperation - GTZ 
ProPSFE have embarked on fostering the Council forest approach (Yufanyi Movuh, 2012). It comes with the argumentation that municipal councils have a much more financial base to embark on forest management activities than village communities would. In the SWR of Cameroon, there are supposedly $18 \mathrm{CFs}$ and 2 proposed Council Forests (Note 20). At the moment classification procedures are being undertaken in the 2 Council Forests (a process which began in 2006). These CFs spread in all the 4 regions of the Technical Operation Units (TOU) (Note 21) of the SWR.

Elaborated reasons from the German Cooperation and MINFOF, for the preference of the council-managed CF model were mentioned. While the communities running the council forest model through the municipal councils have more opportunity of acquiring loans which will enable them to manage the forest, the village communities with the community forest model are less successful in the implementation of the Community forests concept in the SWR and the country at large due to financial constraints. It is argued that under the council, communities have more bargaining power and possibilities to marketing channels. Furthermore, the council forest model is more liable in creating job opportunities for youths in the municipality. For the land tenure contracts signed with the central government through MINFOF, the management convention (MC) with the council is signed for 30 years while that with the community is only 25 years, allowing communities under the municipal council through council forest model of CF communities to acquire an unlimited surface area, while in the community forest model, the communities acquire a maximum of only $5000 \mathrm{ha}$.

\section{Discussion and Conclusion}

Ribot (2004), after an examination of a subset of countries (including Cameroon) implementing decentralization and devolution of forest management, concluded that, "most decentralizations are not being established in law or they are not being implemented in practice". The forest management decentralization in Cameroon is a process defined and controlled by the central state (Oyono, 2004a, b). The results of this paper can only confirm these finding. Furthermore, the paper stresses the lengthy period of acquisition, complication and exorbitance of the whole process. Related to Community forestry, communities can apply for community forests of up to 5,000 ha, under 25 year leases, to be reviewed every 5 years (Hoare, 2006; Yufanyi Movuh, 2012). The communities are supposed to be solely responsible for the management of the forest and receive all the benefits arising from its utilization. Theoretically, a village community can apply for a community forest, which is then reserved for them by MINFOF, awaiting a SMP, which can either be approved or rejected. Practically, this process is slow, long, complex, expensive and centralized and does not lead to devolution of authority as claimed by the government and many international Organizations. Also within the scope of the 1994 Forestry law (article 21) and the current forest and environment sector program (FESP), it became imperative that local councils manage Council forests as part of the decentralization process. The German Cooperation (KfW/GFA, GIZ, Note 22) is working with other partner organizations to provide support to councils nation-wide to create and manage Council forests within their area of jurisdiction (Note 23). For Council forest an agreement is valid for 30 years (Note 24), with an unlimited land area size compared to the 5000 ha of the community forest.

If forest resource decentralization is seen as, any act by which central government formally cedes powers to actors and institutions, enhancing efficiency, participation, equity, and environmental sustainability and CF meant to be forest practices which directly involves local forest users in the common decision making processes and implementation of forestry activities, then the CF models have not yet functioned as a decentralization tool. Although decentralization of local forest management and income offers the local communities an opportunity to derive livelihoods from their forests, the process has also made them to fall under the control of the state and its development partners. Through documents like forest inventories, management plans and conventions between the State and the Communities, they keep the communities abbey, exercising far more authority than even before the implementation of the Forestry law of 1994. With the present CF models, the influence and power of MINFOF and their international collaborators go up, while the power of the communities to control their forest activities is reduced. Thus, the different village committees (CIGs or VFMCs), lacking effective power and sometimes totally cut off from local communities they represent, have become captive to motivations other than the good of the community or the individual forest user (Yufanyi Movuh \& Schusser, 2012). At the end of the day, ceteris paribus, the State is still de jure and de facto owner of the land.

Finally, the natural resource policy in Cameroon is as old as Cameroon itself, but before the arrival of the first colonial administrators in the late $19^{\text {th }}$ century, natural resources were managed according to the people's law or customary law; the village chiefs were the main administrators of resource management (ibid; Oyono, 2009). By creating new organizations (CIGs/VFMCs) for the local management of forest resources and benefits, rather than using indigenous institutions, the architects of decentralization have disabled the existing instruments of social regulation and cleared the way for damageable social distortions and conflicts (Oyono, 2005a). To crown it all, 
there are very weak enforcement institutions designed or put in place to punish or penalize defaulters of the CF regulatory implementation and no monitoring systems to evaluate the successes or failures of the decentralized forest resource management. This has made the present CF models and their establishments, still to be seen as an instrument of decentralization and devolution.

This paper recommends that traditional and customary regulations, practices and rules should be re-evaluated to see if they would not offer a better way of local governance or managing forest resources while involving local people. For this, more research is needed.

\section{Acknowledgements}

This research was partly funded by the German Research Foundation (Deutsche Forschungsgemeinschaft/DFG) and the Open Access Publication Funds of the Georg-August-University Goettingen.

\section{References}

Bikié, H., Collomb, J. G., Djomo, L., Minnemeyer, S., Ngoufo, R., \& Nguiffo, S. (2000). An Overview of Logging in Cameroon. Global Forest Watch / World Resources Institute. Washington DC. Retrieved from http://www.globalforestwatch.org/common/cameroon/english/report.pdf

Blaikie, P. (2006). Is Small Really Beautiful? Community-based Natural Resource Management in Malawi and Botswana. World Development, 34(11), 1942-1957. http://dx.doi.org/10.1016/j.worlddev.2005.11.023

Dahal, G., \& Capistrano, D. (2006). Forest governance and institutional structure: an ignored dimension of community-based forest management in the Philippines. International Forestry Review, 8(4), 377-394. http://dx.doi.org/10.1505/ifor.8.4.377

Devkota, R. (2010). Interests and Powers as Drivers of Community Forestry: A case study of Nepal. Göttingen: University Press Göttingen.

Etoungou, P. (2003). Decentralization viewed from inside: The implementation of community forests in East Cameroon (Working Paper No. 12). Washington, DC: World Resources Institute. Retrieved from http://pdf.wri.org/eaa_etoungou.pdf

FAO. (1992). CF Note 7: Community Forestry: Ten Years in Review. Revised edition prepared by J. E. M. Arnold. Food and Agriculture Organization of the United Nations, Rome, 1992.

Glück, P., Rayner, J., Cashore, B., Agarwal, A., Bernstein, S., Capistrano, D., ... Pleschberger, W. (2005). Changes in the governance of forests resources. In G. Mery, R. Alfaro, M. Kanninen, \& M. Lobovikov (Eds), Forests in the Global Balance: Changing Paradigms. IUFRO World Series, Vol. 17. Helsinki: International Union of Forest Research Organizations. Retrieved from http://www.iufro.org/download/file/6981/153/ws17intro_pdf/

Hoare, A. L. (2006). Divided Forests: Towards fairer zoning of forest lands. A report produced for the Rainforest Foundation UK. Retrieved from http://rainforestfoundationuk.org/files/Divided\%20Forests.pdf

IUCN. (1992). Conservation Atlas of Tropical Forests. Africa. IUCN, Gland, Suisse.

Larson, A. M. (2005). Democratic decentralization in the forestry sector: lessons learned from Africa, Asia and Latin America. In C. J. Colfer, \& D. Capistrano (Eds), The Politics of Decentralization- Forests, Power and People (pp. 32-62). London: Earthscan.

Mambo Okenye. (2004). Community Forest in the South West Province of Cameroon. Lessons Learned Opportunities, Successes and Constraints. GTZ-PGDRN, SW Antenna. Retrieved from http://data.cameroun-foret.com/system/files/18_64_07.pdf

Mambo Okenye. (2006). PSMNR- in Cameroon Feasibility study on creation of Council Forests in the South West Province. Mission Report for GTZ-PGDRN, Buea September 2006. Retrieved from http://data.cameroun-foret.com/system/files/18_61_127.pdf

Mandondo, A. (2003). Snapshot Views of International Community Forestry Networks: Cameroon Country Study, CIFOR/Ford Foundation, March 2003. Retrieved from http://www.cifor.org/publications/pdf_files/CF/Cameroon_CF.pdf

McDermott, M. H., \& Schreckenberg, K. (2009). Equity in community forestry: insights from North and South. International Forestry Review, 11(2), 157-170. http://dx.doi.org/10.1505/ifor.11.2.157

Ostrom, E. (1990). Governing the Commons: The Evolution of Institutions for Collective Action. Cambridge 
University Press, New York. http://dx.doi.org/10.1017/CBO9780511807763

Oyono P. R. (2004a). Institutional deficit, representation, and decentralized forest management in Cameroon. Elements of natural resource sociology for social theory and public policy. Environmental Governance in Africa, Working Paper No. 15, Washington, DC: World Resources Institute. Retrieved from http://pdf.wri.org/eaa_wp15.pdf

Oyono, P. R. (2004b). One step forward, two steps back? Paradoxes of natural resource management decentralization in Cameroon. Journal of Modern African Studies, 42(1), 91-111. Cambridge: University Press. http://dx.doi.org/10.1017/S0022278X03004488

Oyono, P. R. (2005a), Profiling local-level outcomes of environmental decentralizations: The case of Cameroon's forests in the Congo Basin. Journal of Environment and Development, 14(3), 317-337. http://dx.doi.org/10.1177/1070496505276552

Oyono, P. R. (2005b). The Foundations of the Conflit de Langage over Land and Forests in Southern Cameroon. African Study Monographs, 26(3), 115-144. Retrieved from http://repository.kulib.kyoto-u.ac.jp/dspace/bitstream/2433/68242/1/ASM_26_115.pdf

Oyono, P. R. (2009). New niches of community rights to forests in Cameroon: tenure reform, decentralization category or something else? International Journal of Social Forestry (IJSF), 2(1), 1-23. ISSN 1979-2611. Retrieved

from http://www.ijsf.org/dat/art/vol02/ijsf_vol2_no1_01_oyono_community_rights_cameroon.pdf

Republic of Cameroon (RoC). (1994). Law N ${ }^{\circ}$ 94/01 of January 1994, establishing forestry, wildlife and fisheries regulations. Yaoundé, Cameroon: Imprimerie Nationale.

République du Cameroun. (1995). Décret No. 95/531 du 23 Août 1995 Portant Application du Régime des Forêts [Decree No. 95/531 of August 1995 laying down the implementation of the Forestry Law]. Yaoundé, Cameroon: Imprimerie Nationale.

Ribot, J. C. (2004). Waiting for democracy: The politics of choice in natural resource decentralization. Washington, DC: World Resources Institute. Retrieved from http://pdf.wri.org/wait_for_democracy.pdf

Ribot, J. C. (2009). Authority over Forests: Empowerment and Subordination in Senegal's Democratic $\begin{array}{llll}\text { Decentralization. Development and } & \text { Change, }\end{array}$ http://dx.doi.org/10.1111/j.1467-7660.2009.01507.x

Schnell, R., Hill, P., \& Esser, E. (2005). Methoden der empirischen Sozialforschung, 7. Auflage, München (Oldenburg).

Schusser, C., Krott, M., Devkota, R., Maryudi, A., Salla, M., \& Yufanyi Movuh, M. C. (2012). Sequence Design of Quantitative and Qualitative Surveys for Increasing Efficiency in Forest Policy Research. Allgemeine Forest und Jagdzeitung (AFJZ), 183(3/4), 75-83.

Sobze, J. M. (2003). Analysis of implication of forest policy reform on CF in Cameroon: Case study of Lomié. Göttingen: Cuvillier Verlag.

WRI. (2007). Interactive Forestry Atlas Of Cameroon, An Overview (Version 2.0). A world resources institute report prepared in collaboration with the Cameroon Ministry of Forestry and Wildlife. ISBN 1-56973-632-4 Retrieved from http://pdf.wri.org/gfw_cameroon_atlas_v2_english.pdf

Yufanyi Movuh, M. C. (2008). Community-Based Biodiversity Conservation Management: Reaching the Goal of Biodiversity Conservation and Community Development, Master's Thesis, 2007, München: GRIN Publishing.

Yufanyi Movuh, M. C. (2012). The Colonial heritage and post-Colonial influence, entanglements and implications of the concept of community forestry by the example of Cameroon. Forest Policy and Economics, 15, 70-77. http://dx.doi.org/10.1016/j.forpol.2011.05.004

Yufanyi Movuh, M. C., \& Schusser, C. (2012). Power, The hidden factor in Development Cooperation. An example of Community Forestry in Cameroon. Open Journal of Forestry, 2(4), 240-251. http://dx.doi.org/10.4236/ojf.2012.24030

http://cameroun-foret.com/governance/forest-royalties-transferred-councils 


\section{Notes}

Summary of some logging Titles in Cameroon (Bikié et al. 2000; RoC, 1994; WRI, 2007)

\begin{tabular}{|c|c|}
\hline Community Forests & $\begin{array}{l}\text { Established under the } 1994 \text { forest code, community forests are areas within the } \\
\text { Non-Permanent Forest Domain zoned for use by village communities. With technical } \\
\text { assistance from the Ministry of Forestry and Wildlife.s (Ministère des Forêts et de la } \\
\text { Faune. MINFOF) Community Forestry Unit (Sous Direction aux Forêts Communautaires - } \\
\text { SDFC), a village community seeking a forest title identifies a zone not exceeding 5,000 ha } \\
\text { and drafts a simple management plan for approval by MINFOF. Proceeds from community } \\
\text { forest management are used for community development projects. }\end{array}$ \\
\hline Council Forests & $\begin{array}{l}\text { Areas zoned within the Permanent Forest Domain and managed according to an approved } \\
\text { management plan. The objectives of a council forest, along with its final boundaries, are } \\
\text { established during the official classification process. Once allocated, these forests become } \\
\text { the private property of a council; however, the commune must abide by the management } \\
\text { plan in order to retain title to the forest area. }\end{array}$ \\
\hline FMU & $\begin{array}{l}\text { Forest Management Unit: Created under the } 1994 \text { forest code, FMUs are forest management } \\
\text { units zoned within the Permanent Forest Domain (i.e., forests that are zoned for biodiversity } \\
\text { conservation and sustainable management). They are allocated by a competitive bidding } \\
\text { process for a } 15 \text {-year period and require a forest management plan approved by the relevant } \\
\text { administrative authority. (The corresponding term in French for FMU is Unité Forestière } \\
\text { d.Aménagement. UFA.) }\end{array}$ \\
\hline Forest Concessions & $\begin{array}{l}\text { Singly managed units, which may include one or more FMUs, not to exceed 200,000 ha. } \\
\text { SSV. Sales of Standing Volume: SSVs are typically zoned within the Non-Permanent } \\
\text { Forest Domain (i.e., forests zoned for timber extraction, agricultural, mining, and other } \\
\text { uses), but they can also be allocated to nationals within the Permanent Forest Domain. SSVs } \\
\text { are allocated by a competitive bidding process for a maximum of } 3 \text { years, are not to exceed } \\
2,500 \text { ha, and do not require a management plan. (The corresponding term in French for } \\
\text { SSV is Ventes de Coupe. VC.) }\end{array}$ \\
\hline
\end{tabular}

Note 1. Cameroon forestry law definition of CF: A community forest is "a forest forming part of the non-permanent forest estate, which is covered by a management agreement between a village community and the Forestry Administration. Management of such forest - which should not exceed 5,000 ha - is the responsibility of the village community concerned, with the help or technical assistance of the Forestry Administration." Source: Article 3(11) of Decree 95/531/PM of 23 August 1995.

Note 2. The Community Forestry Working Group (CFWG) in Germany, within the Chair for Forest and Nature Conservation Policy of the University in Goettingen.

Note 3. PSMNR-SWR: Program for the Sustainable Management of Natural Resources in the South West Region.

Note 4. These numbers have been adjusted to suit the actual statistical analysis of this paper. Originally in 2009, 19 Community Forests and 6 proclaimed council forest areas were identified.

Note 5 . This was done through the snowball method. It is a typical way to analyse networks.

Note 6. There are four types of legal entities recommended to rural organizations, to be officially recognized and to be institutionalized actors in the community forest process: i) the common initiative group (CIG); ii) the association (Ass); iii) the economic interest group (EIG); and iv) the cooperative.

Note 7. Forming of an entity or Common Initiative Group - CIG (this is one of the foremost steps of the village: it has to be organized as a legal entity, creating an Association, a CIG or other forms of association since the government does not deal with individuals.

Note 8. Natural boundaries are rivers, streams, settlements, mountains; permanent geographical features.

Note 9. Collective convention means that every village has its own area in the CF.

Note 10. the written minutes of the consultation meeting or assembly.

Note 11. The district representative of MINFOF. 
Note 12. The RIGC Project (also a MINFOF project) is a project assisting communities managing community forests, especially in drawing up SMPs and carrying out some training and providing them with basic equipments like chainsaws in the form of a loan, expecting that when the community is operational, then they refund the money for others to use. They are based in Yaoundé.

Note 13. The Provisional Convention gives the rights to the Community to exploit $200 \mathrm{~m} 3$ timber from the forest to finance the elaboration of their MP.

Note 14. SMP is valid for 5 years (and has to be revised after every 5 years) whereas the Management Convention (protocol of agreement between the community and the State) or Management Agreement is valid for 25 years.

Note 15 . AAP is to be approved every year by MINFOF.

Note 16. Village Forest Management Communities (VFMC) is a committee created at the village level to ensure a participatory approach in the management of the forest resources of that village. It is created in all the villages concerned with the Council Forest and is an 8 member committee per village.

Note 17. The Ikondo Kondo village had for a long time applied for its own community forest. After about eight years, it was rejected and later included in the Mundemba council forest. The problem was supposedly later resolved and the area reserved for community forest became part of the council forest.

Note 18. The law no. 94/01 of 20 January 1994 on forestry, wildlife and fisheries regulations.

Note 19. MINTAD/MINFI/MINFOF Ministry of Territorial Administration and Decentralization/Ministry of Finance/Ministry of Forestry and Wildlife.

Note 20. To repeat again, all these were just on paper or on maps. Some are just reserved forests with no Management Plan, Management Agreement or Management Convention.

Note 21. A TOU is a given geographic space (a given ecosystem or an ecologically fragile zone) which is selected due to its socio-economic, ecological, cultural and political importance with the benchmark strongly conforming to the development of an integrated management of natural resources and sustainable development based on an arrangement that assures the sustainable use of the resources by all stakeholders concerned. It is elaborated within the framework of component $\mathrm{N}^{\circ} 3$ of the PSFE, and component $\mathrm{N}^{\circ} 2$ of the PSMNR-Cameroon (PGDRN).

Note 22. These different Organisations have and represent different interests within the PSMNR-SWR although they want to be seen as representing the same interest.

Note 23. Examples of support are the Nguti and Mundemba Councils in the SWR.

Note 24. The Management Agreement has a rotation period of 30 years and is renewable. 